\title{
$\mathrm{PH} 1000_{\text {acuaridad }}$
}

\section{Comunarte visibiliza el patrimonio cultural y la riqueza que aportan las personas migrantes a la sociedad canaria}

Comunarte es un proyecto que comenzó a finales de 2017 para pensar al migrante más allá de las imágenes estereotipadas que nos llegan día a día a través de los medios de comunicación. Basándose en un proceso de investigación etnográfica con perspectiva de género, Comunarte pretende visibilizar el arte y la cultura de las comunidades migrantes residentes en Canarias y generar así nuevos imaginarios sobre la movilidad de las poblaciones.

Silvia Cristina Zelaya Álvarez, Grecy Pérez Amores | Dpto. de Sociología y Antropología, Universidad de La Laguna

Url de la contribución <www.iaph.es/revistaph/index.php/revistaph/article/view/4619>

La finalidad principal de Comunarte es avanzar en la creación y consolidación de nuevos imaginarios para pensar la movilidad y las migraciones mediante una metodología de acción-investigación participativa que permite establecer un diálogo permanente entre nacionales y extranjeros en torno a las identidades, las fronteras y la relación entre arte, movilidad y ciudadanía. El objetivo del proyecto es generar un acervo de las culturas migrantes compuesto por experiencias de investigación interdisciplinares con fines de interés social; artículos académicos de corte etnográfico que puedan circular dentro y fuera de la comunidad científica; acciones artísticas construidas desde la participación ciudadana; nuevos enfoques para pensar las migraciones y contenidos audiovisuales.

Comunarte tiene sus raíces en una investigación realizada en la ciudad de São Paulo, durante el año 2016, financiada por la Coordenação de aperfeiçoamento de pessoal de nivel superior (CAPES), junto a refugiados e inmigrantes que se dedicaban a diversos campos de expresión artística. Durante aquella etapa de trabajo de campo, se realizó una aproximación a dos iniciativas que inspiraron este proyecto. La primera, Visto Permanente, surgida con la intención de visibilizar el patrimonio urbano de las culturas inmigrantes en su riqueza y resistencia. La segunda, O Museo do Estrangeiro, pensada como una exposición itinerante, fluctuante y efímera con la cual se pretendía llamar la atención para las diversas configuraciones en las cuales la condición de inmigrante/migrante se constituye.

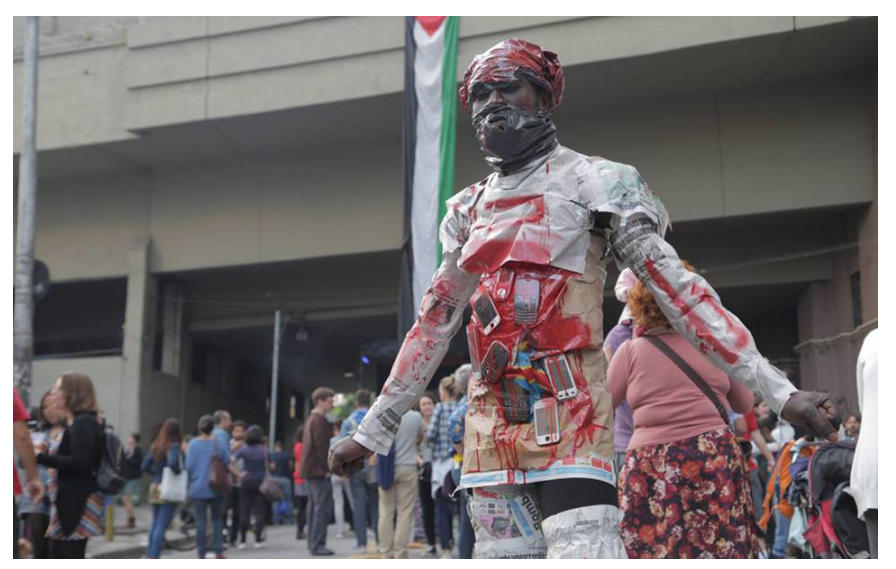

El artista congoleño Shambuy Wetu en São Paulo. Año 2016 | foto Silvia Cristina Zelaya Álvarez, autora de todas las imágenes que ilustran esta contribución

A finales de 2017, Comunarte inicia su andadura en Tenerife, sumándose a la propuesta la antropóloga de la Universidad de La Laguna Grecy Pérez Amores. A mediados de 2018, el proyecto recibe financiación del área de Cultura del Gobierno de Canarias a través de la empresa pública Canarias Cultura en Red y el apoyo de instituciones culturales públicas y privadas canarias. En una primera etapa, la idea pasa por conectar personas y construir una red de artistas e iniciativas culturales para el intercambio de experiencias y la visibilización de la(s) movilidad(es). Así, en diciembre de 2018 realizamos el primer encuentro en la biblioteca municipal Adrián Alemán de Armas, de La Laguna. Para iniciar el diálogo sobre lo que significa ser un inmigrante, emigrante, refugiado, sobre las fronteras y el arte como forma de participación política, invitamos a artistas (in-e) 
migrantes residentes en Canarias a hablar de y desde su trabajo artístico. Se trató de un abordaje sobre la cuestión migratoria que, alejado de la tradicional perspectiva acerca de la migración como "problema", apostó por un tratamiento desde su intersección con el arte. Esto se justifica porque si observamos las imágenes con que cada día son visibilizados los migrantes -inmigrantes, emigrantes, refugiados- en los medios de comunicación, es frecuente que nos encontremos con imágenes que si bien no nos dejan indiferentes, suelen apelar a la compasión y a nuestra sensibilidad, dejando poco espacio para otras reacciones. En otros casos, estas mismas representaciones son usadas como argumentos en contra de la inmigración. Está claro que si bien la representación de la vulnerabilidad en el espacio público no es la causa del malestar, ayuda a consolidar una imagen tendenciosa que coloca a los inmigrantes solamente como pobres e víctimas que precisan de atención pero nunca como personas que pueden aportar algo a la sociedad receptora.

En 2019 continuamos analizando las conexiones entre las personas y sus movilidades a través de una ardua revisión bibliográfica y un exhaustivo trabajo de campo incluyendo la itinerancia entre islas. Entre enero y julio de 2019 hemos realizado tres viajes a las Palmas de Gran Canaria y establecido contacto con artistas residentes en otras islas como por ejemplo el Hierro y Lanzarote. Con el objetivo de visibilizar el trabajo de los y
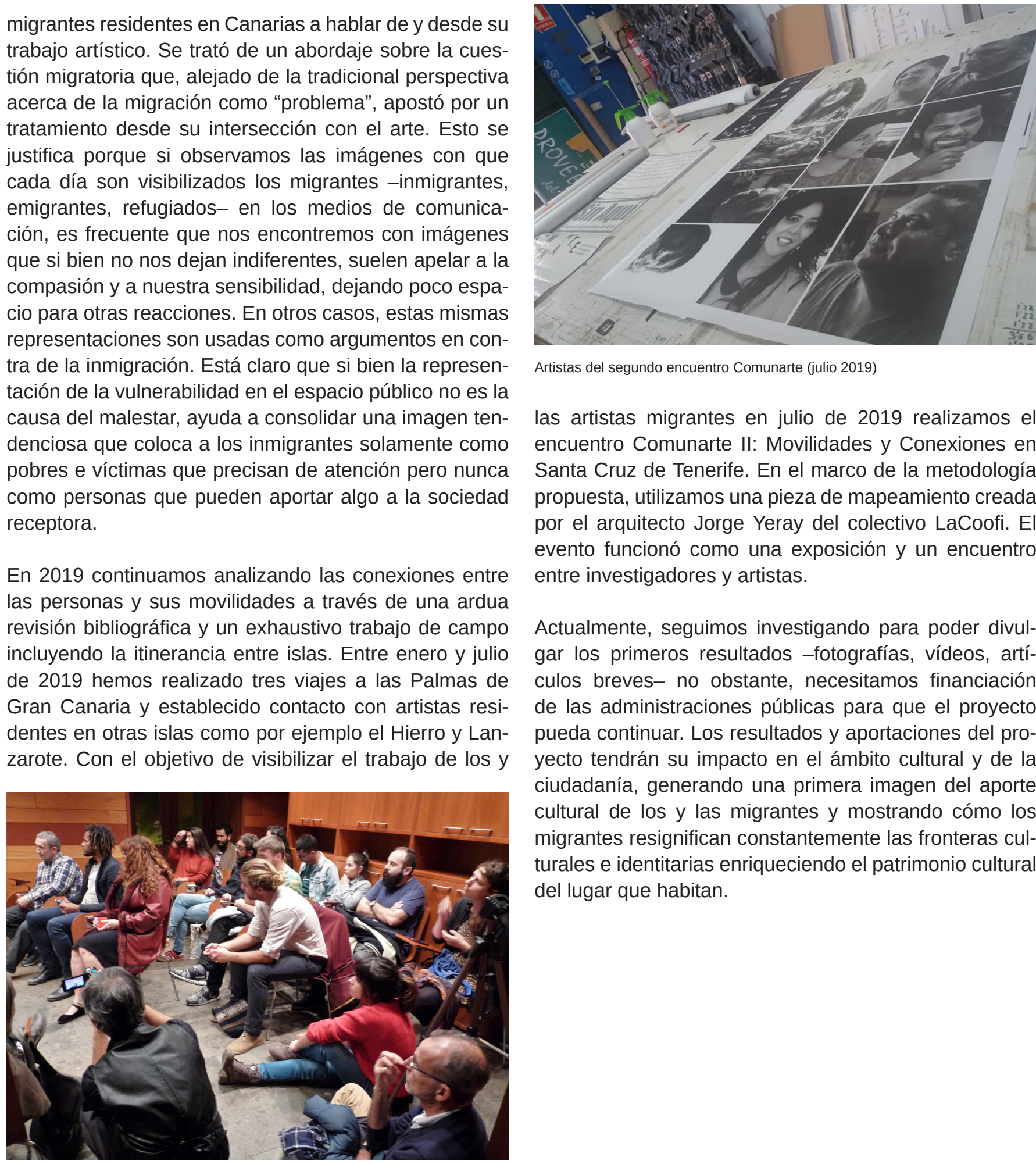

Artistas del segundo encuentro Comunarte (julio 2019)

las artistas migrantes en julio de 2019 realizamos el encuentro Comunarte II: Movilidades y Conexiones en Santa Cruz de Tenerife. En el marco de la metodología propuesta, utilizamos una pieza de mapeamiento creada por el arquitecto Jorge Yeray del colectivo LaCoofi. El evento funcionó como una exposición y un encuentro entre investigadores y artistas.

Actualmente, seguimos investigando para poder divulgar los primeros resultados -fotografías, vídeos, artículos breves- no obstante, necesitamos financiación de las administraciones públicas para que el proyecto pueda continuar. Los resultados y aportaciones del proyecto tendrán su impacto en el ámbito cultural y de la ciudadanía, generando una primera imagen del aporte cultural de los y las migrantes y mostrando cómo los migrantes resignifican constantemente las fronteras culturales e identitarias enriqueciendo el patrimonio cultural del lugar que habitan.

Primer encuentro Comunarte (diciembre 2018) 